\title{
THE GENIUS LOCI AT THE GREAT TEMPLE OF ABU SIMBEL. HERMENEUTIC READING IN THE ARCHITECTURAL LANGUAGE OF ANCIENT EGYPTIAN TEMPLES OF RAMSES II IN NUBIA
}

\author{
Nelly Shafik Ramzy

\begin{abstract}
Archaeologists have long wondered about the Temple of Abu Simbel: its location within the Nubian territory far from major Egyptian cities, and its unique design. Utilizing the hermeneutic process of understanding the whole from the parts and then situating the whole within a bigger whole (context), this study is a trial to arrive at a better interpretation of this monument. Drawing on the characteristic analysis of the temple's Genius Loci as developed by Norberg-Schulz, as well as on Heidegger's anticipatory fore-structures, the study goes on to show that both of the location and the unique structure of the temple were the outcome of political and conceptual aspects of the period, more than being a religious tradition. Reaching this conclusion, another goal had been achieved, where the validity of hermeneutic analyses as a useful tool for discovering new dimensions about historical monuments and archaeological sites had been attested.
\end{abstract}

Keywords: Hermeneutics, Phenomenology, Architectural language, Abu Simbel, Ancient Egyptian architecture.

\section{INTRODUCTION:}

D henomenology, as initiated by Edmond Husserl, is an umbrella term encompassing both a philosophical movement and a range of research approaches. Martin Heidegger and Hans-Georg Gadamer recast Husserl's project, moving away from the philosophical discipline towards hermeneutic (interpretive) dimensions. Since then, phenomenology has been viewed from multiple perspectives as a philosophy, methodological approach, and interpretive theory, enfolding three main forms: existential, transcendental, and hermeneutic phenomenology. ${ }^{1}$

The focus of hermeneutic phenomenology is towards creating meaning and achieving a sense of understanding. ${ }^{2}$ In this, Heidegger emphasizes on historicality as a basic concept of the process of understanding, which is shaped by a horizon of concepts, assumptions, effects, habits, stories, images, and convictions that evolves through a "dialogue with the past." "3

Drawing on Heidegger's theories, Norberg-Schulz, Karsten Harries, and

GRONDIN 1994, 2

WILSON/HUTCHINSON 1991, 263-276

3 HEIDEGGER 1993, 361-362

DOI: $10.14795 /$ j.v2i 2.106

ISSN 2360 - 266X

ISSN-L 2360 - 266X 
others developed several hermeneutic/phenomenological concepts that recover architecture's symbolic and linguistic power. In the 1970s, phenomenology began to have a major impact on architectural theory. Christian Norberg-Schulz was the major figure in this movement and his book Genius Loci was the most prominent reference in this field. The term Genius Loci was used by ancient Romans to refer to the guardian spirit of places. In contemporary usage, it refers to a location's distinctive atmosphere, or a spirit of place. ${ }^{4}$ Genius Loci means that there is more to a space than its physical dimensions, or as $\mathrm{K}$. Harries puts it "a meaning that can be voiced in a language experienced in its visual, tactile, and kinetic sensuousness." ${ }^{5}$ Yuri Artibis calls this spirit the contextual place, explaining it as: "the genetic footprint of a

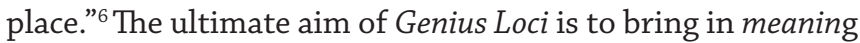
into places and create architecture that is not just an aesthetical exercise; neither is it a technological statement.

Great historical monuments have been always measured and analyzed to learn about their proportions, dimensions and materials, not considering a reading of their "phenomena" beyond form and function to matter and presence.

Ancient Egyptian architecture has generally remained within the bounds of empirical study, its monuments being subject of description, stylistic/formal analysis, and taxonomic studies. A contextual history of the builder's perception of their creations is still a major lacuna. It is this gap that this research attempts to take a step towards filling it, by conducting a hermeneutic analysis of one of the most curious and unique structures of this civilization: the Great Temple of Abu Simbel. The study has a two-fold goal: the first is to come up with an interpretation to the architectural discourse embedded in this "architectural text"; and the second is to challenge the validity of hermeneutic analyses as a useful tool to discover new dimensions in historical architecture and archaeological sites.

Reaching this goal, the study is organized into five parts.

1. Introduction: that highlights the outlines of the study;

2. Methodology: in which hermeneutics analysis, as developed by Heidegger and Norberg-Schulz, is suggested as a methodological framework for the temple's interpretation;

3. Analytical part: in which the layers of meaning comprised in the "phenomenon" of the temple are to be discovered;

4. A summery and discussion of the results;

5. Conclusion, in which the validity to understand this architectural text by hermeneutic methods is attested and the statement included in the building is revealed.

\section{METHODOLOGY:}

For the interpretation of a non-verbal text, Heidegger defines two modes of interpretation; the road to understanding is articulated by one of them or both of them together: the first mode addresses the characteristics of a "thing" as the first layer that people encounter; the second is the conception of

\footnotetext{
ARTIBISE 2010, http://yuriartibise.com/what-is-genius-loci/ HARRIES 1997, 85-89

6 ARTIBISE 2010, http://yuriartibise.com/what-is-genius-loci/
}

the thing as a unity of manifold sensations and backgrounds. The first mode regards the thing as formed matter, while the second mode regards its content. ${ }^{\text {? }}$

By reviewing Heidegger's writings, two sets of notions for the understanding of a thing are to be realized. The first set is the so called fourfold, which are characteristic aspects that concerns the way a thing "gathers" its surrounding (earth, sky, divinities, and mortals) and the way it is manifested in a formal character.

In a trial to interpret Heidegger's fourfold into architectural language, Norberg-Schulz introduced the concept of Genius Loci. He identifies the methodological aspects, through which Genius Loci conveys the character of places, as: image, space, and character. ${ }^{8}$ He interprets these criteria into three-steps-strategy that includes: the distinction of natural from man-made, the qualification of the inside and outside of the space, and the assessment of the character. ${ }^{9}$ For the later step, further four thematic layers are to be explored:

- Cultural landscape

- Cosmological light and natural conditions

- Overall structure;

- Symbolic and existential values. ${ }^{10}$

As a condition for the second mode of conceptual interpretation, Heidegger identifies a second set of notions through what he calls the anticipatory fore-structures that occur as the prelude of the thing in reference to its "historicality". These are: the fore-sight, which concerns the specific point of view, from which the thing is to be understood; the forehaving which is the background of the thing, or how and from what did it develop; and the fore-conception, which is the preknowledge upon which the interpretation should be based..$^{11}$ In the following, both of these two sets of hermeneutic interpretation are to be applied on Ramses's temple.

\section{ANALYSIS:}

The Great temple of Abu Simbel was commissioned by Ramses II about 1264 B.C. and was finished about 1244 B.C., coinciding more or less with Ramses's 30-year jubilee.

Four colossal 20 meter statues of the Pharaoh, directly sculptured from the rock, decorate the 35-meters-wide trapezoid facade, topped by a frieze of 22 praying baboons. Between the legs of the colossal statues are small statues of Ramses's family, his mother Mut-tuy, his wife Nefertari, and his sons and daughters.

Above the entrance doorway, in the center of the façade, is a large figural relief giving the Pharaoh's name in the form of a rebus (Fig. 1). In the middle is the falcon headed Ra-Harakhti inside a large niche, flanked by the jackal headed staff known as user and by $M a$ 'at, goddess of truth and justice. ${ }^{12}$ Taken together, they give Ramses's coronation name, User-Ma'at-Ra, in a gigantic cryptogram. On either side of the relief are representations of Ramses making offerings to the gods and to his own deified name.

Beside this temple is the smaller Temple of Nefertari and Hathor, the design of which is very similar to that of
HEIDEGGER 1993, 143-212
NORBERG-SCHULZ 1980, 67-81
EL-BIZRI 2011, 47-71
JIVE'/LARKHAM 2003, 67-81
HEIDEGGER 1993, 143-212
TYLDESLEY 2001, 105 


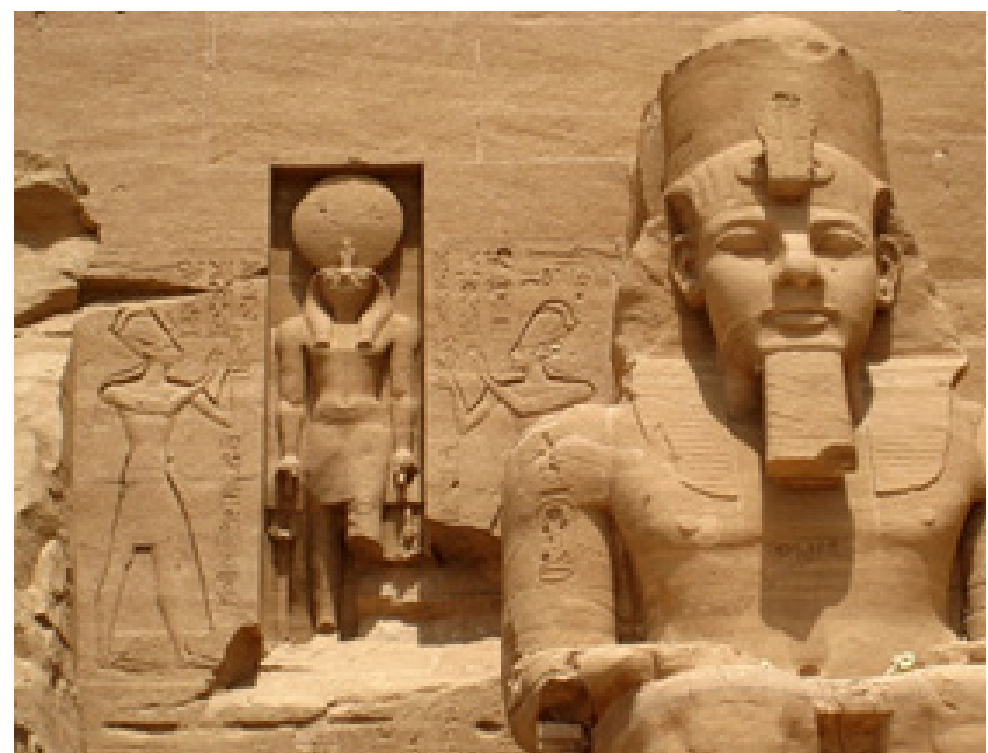

Fig. 1. Ramses II's coronation name above the entrance of the temple

Ramses. The entire temple-complex was nearly covered with sand for many centuries until John Burckhardt discovered it in 1813. The discovery was completed by Giovanni Belzoni in 1817. The two temples were relocated on a higher ground in 1963 - 1968 to avoid being flooded, when Lake Nasser was created.

\subsection{Norberg-Schulz's Genius Loci}

In the following is a characteristic analysis of the temple according to the thematic features of Genius Loci as suggested by Norberg-Schulz:

\subsubsection{Image: The setting and its natural configuration}

Norberg-Schulz defines three possible ways of interpreting the relationship between man-made architecture and the natural aspects of the place, or how a building "gathers" the landscape. These are: to Visualize - where a building replicates the nature; to Complement - where a building adds what is lacking in nature; or to Symbolize - where a building translates the hidden meanings in nature onto built form. ${ }^{13}$

Looking at the original setting of the temple (Fig. 2), one realizes at once that neither of the first two concepts could be applicable here; the building neither replicates the surrounding nature, nor does it make a clear addition to it, but rather looks like a "seal" on the surface of the mountain. The third concept seems, therefore, more applicable here. But, how does this "seal" symbolize the nature around it? And what did the ancient Egyptian architect saw in the nature of this spot to be symbolized in this way? ${ }^{14}$

The original setting of the temple was in the "solid rock" directly on the bank of the Nile River between the First and Second Cataracts, as if it rises out of the waters (the temple in its original site was only two meters away from the water $)^{15}$. Prior to the dams, the river gathered speed at the First Cataract, dropping in swirling eddies and turbulent falls of water for a distance of three miles. The river in this area was, then, over 35 meter deep, with confusing waters that could twist and turn in all directions. The trek of water was so hazardous that some travelers, until relatively modern times, made their devotions before continuing through this territory that was called the "Land of Ghosts," where codices from the Middle Kingdom record that it was considered a "Sacred Spot."16

It is also notable that, unlike many other ancient Egyptian temples, Abu Simbel was never taken over by the Romans or turned into a church, which means that it had been covered by sand since very ancient times. This means that: first, the area was not visitable; and second, the weather there was so blustery that it could accumulate such amounts of sand over the temple, regardless of the annual flood, which certainly used to remove a considerable amount of sand each year. Yet, what remained of the sand was enough to fully cover the temple by the time of the arrival of the Romans.

The temple's overwhelming appearance was, thus, a declaration of this solid, hazardous nature of this territory. The (at this time) unexpected four colossi with their extraordinarily huge size and serious appearance were certainly a further intimidation for any passerby.

\subsubsection{Space: Inside- outside configuration}

The most important elements that unify the interior and the exterior of this temple are: a) the unusual design; b) the solid earthy look of the walls; and c) the themes of the art works and moral reliefs that also contributes to the idea of solidity and strength, conveying two specific messages: the first is that Ramses puts himself in an equal status to that of the deities; and the second is an alarming message to the enemies, especially the Nubians.

The temple's interior arrangement is quite unusual because of its many (eight) side chambers. Traces of soot

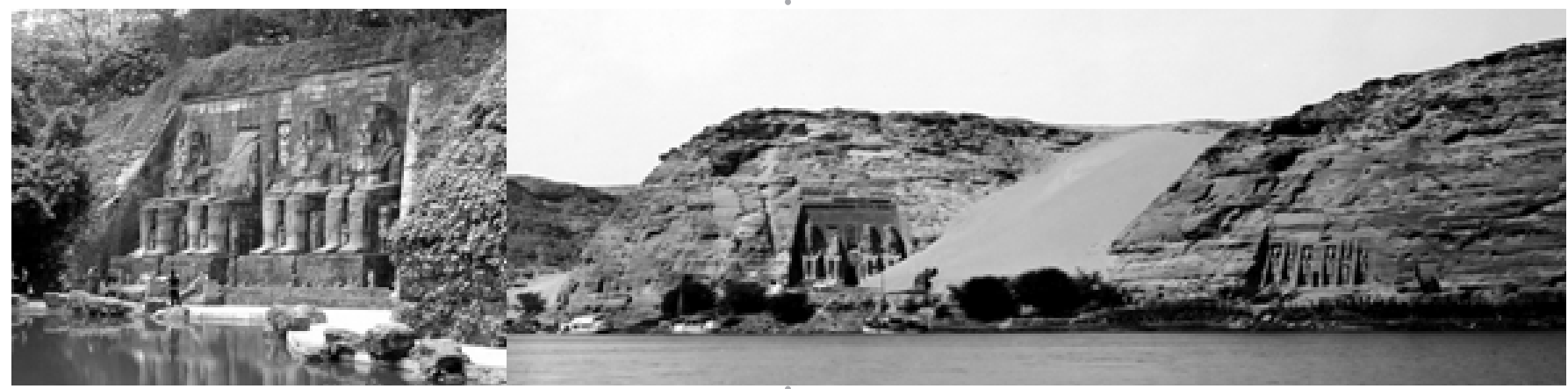

Fig. 2. The temple complex in its original setting in 1904, with a bank of sand separating the two temples.

NORBERG-SCHULZ 1980, 17
14 Ancient-wisdom, http://www.ancient-wisdom.co.uk/egyptabusimbel.htm 15 SALEH, http://www.ancient-wisdom.co.uk/egyptabusimbel.htm 16 WEIGALL, 1910, 560-566 
and the stone tables along the walls show that they served for some activities other than ritual, such as clerical activities or as treasuries. ${ }^{17}$ The effect produced on first entering the temple is more striking than that of any other temple. The loftiness of the ceiling, the imposing height of the pillars with the erect colossal statues attached to them, and the dimensions of the chambers, which are of a much larger scale than any of the other temples, all contribute to render the interior no less overwhelming than the exterior.

Beyond the entrance is the Hypostyle Hall, with eight 10-meters-high pillars of Ramses defied as Osiris. The ceiling of the central aisle has paintings of flying vultures; those of the lateral aisles are adorned with stars. Beyond the Hypostyle Hall is a Vestibule, from which the sanctuary is entered, where four over-life-size figures of (from left to right) Ptah, AmunRa, Ramses himself, and Ra-Harakhti are seated facing the entrance. In front of the figures is the rock-hewn base of the sacred barque, which is most likely the barque of the defied Ramses. ${ }^{18}$

As for the mural reliefs, from outside, along the front of the terrace, representatives of people from different nations are depicted making obeisance to the Pharaoh. On the thrones' sides of the two central colossi, flanking the entrance, are figures of the two Nile gods wreathing the floral emblems of Upper and Lower Egypt in reference to the unity of Egypt under Ramses's rule, while below are rows of prisoners; on the left Kushites (Nubians) and on the right Syrians. In these scenes, the soldiers are depicted counting the torn hands of Kushite casualties, ${ }^{19}$ while Kushite prisoners are displayed to Amun, Mut, and the deified Ramses.

On the right side of the entrance wall, the Pharaoh, accompanied by his $k a,{ }^{20}$ is shown smiting his enemies in the presence of Ra-Harakhti; on the left wall is a similar representation of the Pharaoh in the presence of Amun-Ra. On the northern wall are scenes from Ramses's campaign against the Hittites. On the rear wall, half of the wall shows Ramses leading two files of Hittite prisoners into the presence of ReHarakhti, his own deified effigy and Wert-hekaw. On the other half, he presents Kushite prisoners to Amun, the deified Ramses and Mut. On the southern wall, in the upper register are five reliefs, notable among them shows Ra-Harakhti under the sacred persea tree; the fruits of which bear Ramses's name. In the lower register are two large scenes: to the left is the Pharaoh storming a Syrian fortress, and to the right his triumphal return from a battle bringing African prisoners.

On the south wall of the Vestibule Ramses and Nefertari are depicted before the sacred barque of Amun of Napata (Nubia city). ${ }^{21}$ In the other half of the scene, Ramses offers wine to Ra-Harakhti. On the Pillars Ramses is shown being elected by Horus of Aniba, Horus of Abu Aimbel, Horus of Kuban, and Horus of Buhan (also Nubian cities). ${ }^{22}$

\footnotetext{
17 PLANETWARE, http://www.planetware.com/nubia/abu-simbel-egy-aswabusim.htm

18 KITCHEN 1982, 64-65

19 The tradition of the torn hands was applied only to dead victims and not to living war-captives.

20 The soul of the person which unites with him after death

21 TÖRÖK 2009, 250

22 It is almost impossible to distinguish the "original" Horus from his many forms. In fact, Horus is mostly a general term for a great number of falcon gods. Ra-Harakhti, or Horus of the two horizons, is a combined god of Horus and Ra. Mandolis, to whom Kalabsha Temple is dedicated, is a Nubian version
}

The same deities appear in the north and south side chapels. ${ }^{23}$

The overall scheme of the temple was, thus, to address those, who may decide to sail in this region (the Nubians), to carefully consider their fate. ${ }^{24}$ The four seriously looking colossi were in their reception. If they dared to come ashore, they would be greeted with a long wall of carvings that demonstrated the military might of the Pharaoh against the Nubian people. As they approach the entrance to the temple, they would see representations of the tribute that Ramses forced the Nubians to pay him and his scenes smiting other Nubians. Over their heads, they will see the flying vultures on the ceiling. They will be also encountered by myriad depictions of the Pharaoh as a fearful, invincible god all over the temple.

\subsubsection{Character/ Characterizing attributes:}

For Norberg-Schulz, the character of place as "total phenomenon" 25 is an outcome of several attributes. In the following these attributes, as they come in the temple, are discussed.

\section{I- Cultural landscape:}

Norberg- Schulz gives a special place to the conception of cultural landscape, distinguishing four basic categories of landscape: Romantic landscape, which depends on "diverse, flexible elements with less order," as in the Nordic Forest; Classical Landscape, where "the earth rises up without drama and blossoms in trees," as in the city of Tuscany; Cosmic Landscape, which has "eternal character and obeys monotonous, unified order," as in the Arab deserts; and finally Complex Landscape as reserved for those sites that has "various kinds of synthesis," as in the volcano island in Greece. ${ }^{26}$

By considering the four categories, the last category of Complex Landscape is found to be best applicable on the site of Abu Simbel, which includes a mountain, a river, and a desert. Norberg-Schulz describes this kind of landscape as "paradoxical and merged" and describes its Genius Loci as having "the characters of peace, extension, domination and isolation all together." 27

In Ancient Egypt, mountains were seen as pillars, or "corrugated rim," on which the sky rests. ${ }^{28}$ The mountainous site of Abu Simbel was certainly seen as part of the rim. ${ }^{29} \mathrm{On}$ the other hand, they saw the Nile, not only as the source of life, but also as chthonic force that destroys everything that comes in its way as it floods. It is the kind of sites where, according to Norberg-Schulz, "the two poles of nature [the mountain and the river] are gathered."30

As a cult temple, the location of the temple on the western side of the Nile is so mystifying, where this side of the valley was reserved for mortuary temples. Cult temples, of Horus.

23 TÖRÖK 2009, 251

24 WELLS, http://www.soulofamerica.com/ancient-nubia.phtml

25 NORBERG-SCHULZ 1980, 28

6 NORBERG-SCHULZ 1980, 42-47

7 NORBERG-SCHULZ 1980, 47

28 NORBERG-SCHULZ 1980, 36

29 Directly opposite to Abu Simbel on the eastern Nile bank is Adda Mountain, which is also a steep sandstone headland that served as a dramatic location for several rock-carved stelae of ancient Egyptian officials.

${ }^{30}$ NORBERG-SCHULZ 1980, 37 
such as Luxor and Karnak temples, were erected on the eastern side, which was the land of life, from where the sun rises, while the western side is the land of the underworld, where the sun sets (as in the Amduat ${ }^{31}$ ). Thus, for some reason Ramses wanted to put this cult temple in the land of the "underworld". Nevertheless, he did not put it in the zone of mortuary temples in Western Thebes (the so-called Valley of the Kings), but rather about $500 \mathrm{~km}$ to the south of it. More significant is yet, that all the other temples built by Ramses in the same region (Nubia), except for the temple of Wadi-AlSebua, were all built on the western bank of the Nile.

\section{II- Cosmological light and natural conditions:}

From outside, the temple enjoys the sort of light that Norberg-Schulz describes as "an almost shadow less light, [which] seems to make an eternal order manifest distinguished by permanence and structure." 32 Quite on the contrary, the very dim interior is pierced only by a beam of sunlight coming from the entrance. The lack of free circulation of air and the arid weather of the region result in extreme heat during the day and extreme coolness at night, adding more apprehensive effect on the visitor.

The solar phenomenon ${ }^{33}$ in the sanctuary is one of the most significant features of this temple. The relationship between this phenomenon and the dates of Ramses's coronation and birthday had been contested by Kitchen. The scholar proved that Ramses's coronation took place in June $18,{ }^{34}$ whereas Parker suggested other occasions to have been marked by these dates, saying that the Egyptian year was divided into three seasons: akhet (Inundation), starting in June 21; peret (Growth), starting at October 21; and shemu (Harvest), starting at February 21. So, the phenomenon may have been considered as a "divine" starting sign from the God/ Pharaoh for the beginning of planting and harvest seasons. ${ }^{35}$

This phenomenon may have another possible connotation: In ancient Egypt, three was the number associated with the concept of unity inherent in plurality. In the New Kingdom, Amun, Ptah, and Ra were regarded as a trinity, who are distinct gods but with unity in plurality and in whom all gods are united. ${ }^{36}$ This is expressed in Leiden hymns: "All gods are in three: Amun, Ra and Ptah, whom none equals... The three gods are one, He who hides his name as Amun, He appears to the face as $R a$, His body is Ptah." 37 Thus, a possible interpretation to this phenomenon is that "He, who appears to the face as Ra (the sun deity)," appears here on the face of Ramses in the shape of sun rays, making Ramses the "He" in the hymn.

In addition to their religious value, these three gods had also political significance, being the State Gods of the New Kingdom: Ra-Harakhti for Heliopolis, Ptah for Memphis and

\footnotetext{
31 The Ancient Egyptian funerary text of the New Kingdom; literally it means "That Which Is In the Afterworld", also called the "Book of What is in the Underworld"

32 NORBERG-SCHULZ 1980, 45

33 Every year on February 22 and October 22 (originally February 21 and October 21), which are probable dates of Ramses's coronation and birthday, the rays of the rising sun penetrate into the sanctuary and fall on his face

34 KITCHEN 1982, 138-139

35 PARKER 1950, 26

36 MORENZ 1992, 144-145

37 ASSMANN 2008, 64
}

Amun-Ra for Thebes. ${ }^{38}$ By joining them on the same bench and with the same size, Ramses was probably declaring himself the god of a fourth region -- Nubia.

\section{III- Overall structure:}

Architecturally, the scheme of this temple is not so easy to be classified under the same category of the other god's mansions. It exhibits more simplicity in its overall conception, yet it includes unparalleled aptitudes in its uniquely sculpted form that grants it a distinctive presence. The quality of the form is a result of an interaction between natural forces and adopted cultural forces that result in a kind of a sense that Norberg-Schulz describes as "rustic simplicity [which] brings nature close." This sense, he adds, grants the Genius Loci of the place "a feeling of rootedness." 39

Heidegger in his assessment of the Greek temple alludes to its "standing" that "links its surrounding to each other." ${ }^{\prime}$ But, unlike ordinary buildings that conquer the nature to stand upon it, rock-cut temples like Abu Simbel fully integrate into the nature and instead of defeating it and standing upon it, it looks like a shield that protects it and merges its magisterial presence with the nature's solemn character and "gathers" its surrounding in a more natural and eternal relationship.

Another aspect of the temple's presence is what Heidegger calls "a place's memorable qualities." ${ }^{41}$ He claims that, nearness is not only a function of mathematical increment, but it relates as much to the "projective identification of places"; those appreciated through imagination and memory. In Abu Simbel, the four 20-meters-rock-cut-colossal figures are certainly one of the most memorable, and most imagination-triggering, images one may think about at this time. They are brought out so fully that the backs do not touch the wall and it is believed that they were once covered by coloured stucco to bring a full life to their image. ${ }^{42}$ The unique architectural expression of the temple brings to mind not only a simple image of a great monument, but a compounding of multiple, multivalent metaphors, evoked by the associations of the mountain, sky, water and light with the mass of the façade.

In ancient Egyptian writing, the hieroglyphic sign for "mountain" (djew) $\checkmark$ and that for "horizon" (akhet) $\bigcirc$ are closely related. ${ }^{43}$ The horizon was imagined to be protected by the Aker; a double lion deity who guarded both ends of the day. The Great Sphinx of Giza, thus, came to be viewed as a literal Horus in the Horizon that lay between the twin peaks of a giant akhet formed by the two pyramids of Cheops and Chephren (regardless that they are not of equal heights). An akhet was also found at the entrance of every country of the Duat.

This hieroglyph was applied in architectural forms, where the pylons that used to flank temples' entrances may well have signified the two peaks of akhet. The statue of the sun god was sometimes displayed from the terrace between

\footnotetext{
REDFORD 2002, 332, 352

9 NORBERG-SCHULZ 1980, 149

HEIDEGGER 1993, 143-212

SHARR 2007, 63

IRBY/MANGLES 1823, 12

BUDGE 1959, 148
} 
the pylons. ${ }^{44}$

In Abu Simbel, there are, oddly enough, no pylons; the designer may have meant the two temples, as enclosed in the two mountains, to be in themselves a giant Akhet for the southern gate of the Nile Valley, as were the pyramids for its northern gate.

Another horizon is to be seen inside the temple. As defined by Heidegger, the horizon is "where earth meets sky." 45 . Inside this temple, encountered by the heavy rockhewn walls of the interior, one thinks of an earth reaching up to the sky of hovering stars and flying vultures, to make another horizon from inside.

\section{IV - Symbolic and existential values:}

Ancient Egyptian architecture had a highly symbolic content, in which ornaments, formal expression, numerical references, orientations, sizes, ... etc. were employed. The temple at Abu Simbel contains myriad symbols; the following are only some of the most notable of them.

Twenty-two baboons used to decorate the frieze and cornice of the entrance, of these only twelve remained. The baboon was closely associated with the god Thoth as his "sacred animal" and was considered as "worshiper of the sun." 46

In the Amduat, Baboons were said to be the guards of the first gate of the Duat, ${ }^{47}$ who "open the first gate of the Duat for the boat of Ra" at each dusk. Four baboons were also described as sitting on the corners of the Lake of Fire in the Duat. ${ }^{48}$ The pool inside the sanctuary of the temple, surrounded on all four sides by fire signs and graphic "dripping of flames" with four baboons on its corners, was clearly symbolizing this lake. ${ }^{49}$ The baboons guarding the entrance and the lake of fire inside the sanctuary (Fig. 3) are two of the strongest signs for a purposeful resemblance between this temple and the image of the Duat. This resemblance is further observed by considering the three gods associated with the temple of Abu Simbel, Ptah, AmunRa, and Ra-Harakhti, as well as Osiris; who are the main gods associated with the Duat. Features that bear resemblance between the Duat and the temple were probably meant as a more intimidating sign, because the Duat is the place, "which evil-doers fear, for their punishment awaits them," and where they fall at last "into the Pool of Fire". "Life of the Gods" is the name of the last country of the Duat. ${ }^{50}$ This last country, where "Gods live," was probably the sanctuary, where the pre-rooms are the previous countries, where "punishment was awaiting for the evil doers"-- in this case Ramses's enemies. The similarity between the temple and the Duat might have a further symbolic connotation, where inside this temple, as in the Duat, the ba of Ra unites with his body (Ramses), when the sun begins its regeneration (in the solar phenomenon). It was also believed that the dead Pharaoh should take this journey, ultimately to become one with $R a$ and live forever. ${ }^{51}$ Having the topographical features of the Duat in the temple may have meant that Ramses have already taken his journey and already became one with $R a$.

Another highly symbolic element in ancient Egyptian architecture was the pillars. The Djed (the pillar) II $_{\text {is }}$ an ancient Egyptian symbol for stability and endurance. The djed image has been interpreted in several ways; one of them is that the four pillars (as on the sides of the Hypostyle Hall), as represented by four parallel bars, were considered the

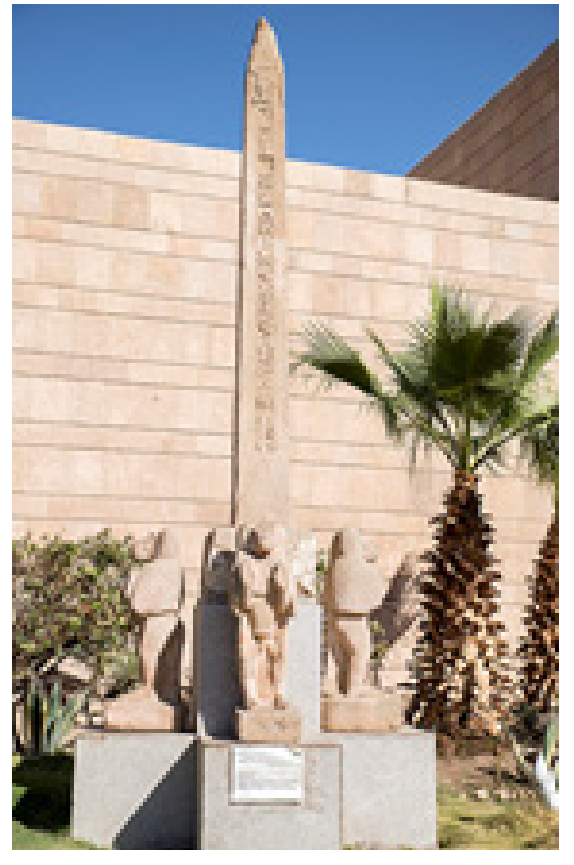

44 WILKINSON 1992, 57

45 HEIDEGGER 1971, 172

46 SOLLEH 2011, 213

47 The Duat is the realm of Osiris and the residence of gods and supernatural beings. It is the region through which Ra travels daily from west to east, from sunset to sunrise, and where he battled Apep. It is a realm of the underworld, where people's souls go after death for judgment, though that was not the full extent of the afterlife.

48 FAULKNER/GOELET 1994, 168

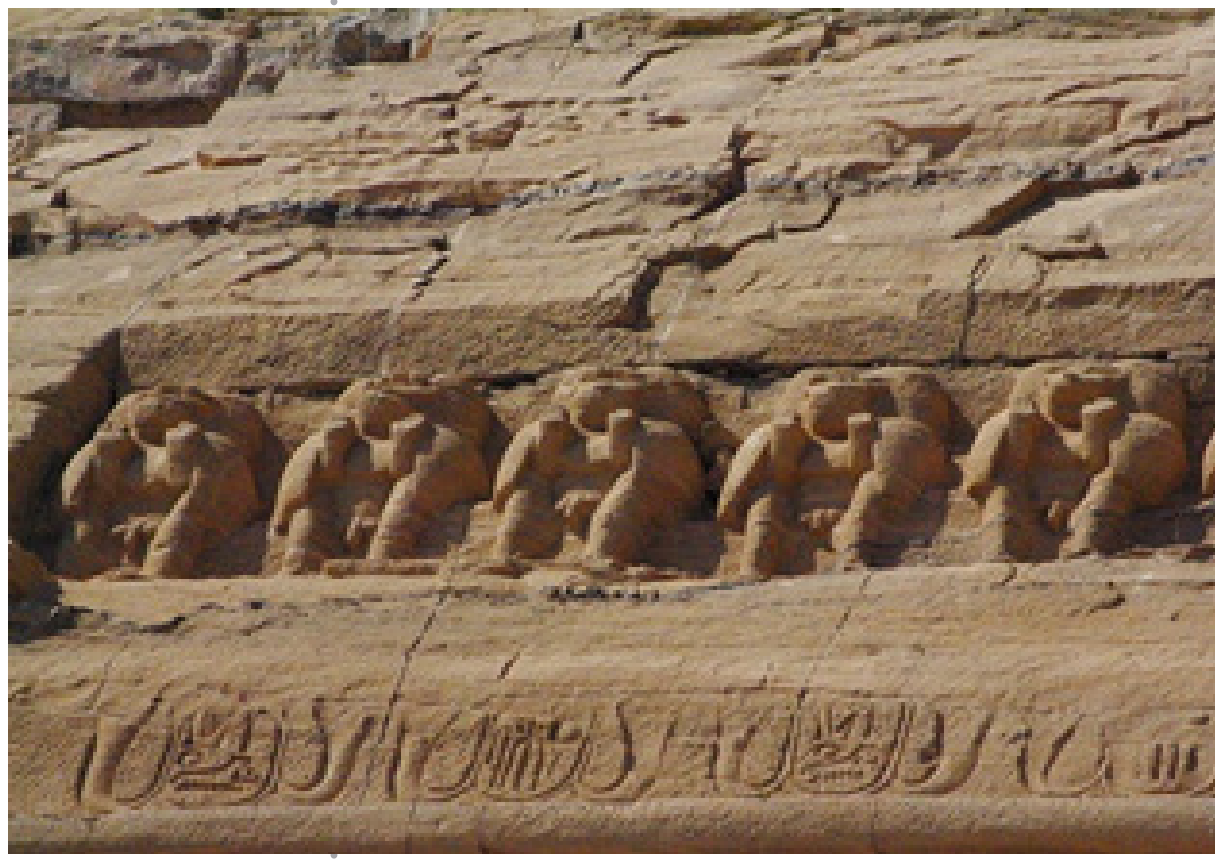

Fig.3. Baboons: (left) the four Baboons that originally stood on the corners of the pool in the sanctuary of the temple, now preserved in Nubia Museum at Aswan, and (right) the Baboons' frieze above the temple's entrance.

\footnotetext{
WILKINSON 1992, 67

MURRAY 1920, 104

FORMAN/QUIRKE, 1996, 168
} 
a

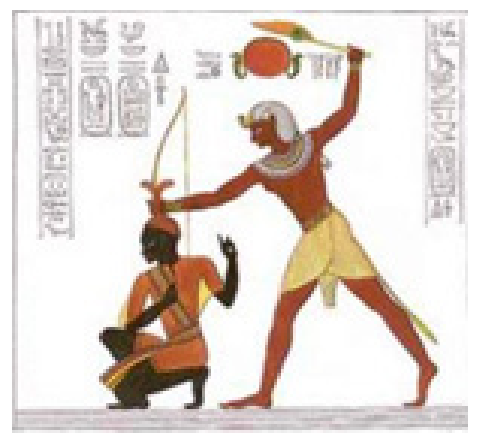

$\mathrm{b}$

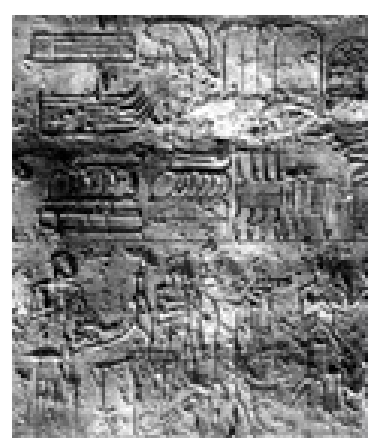

C

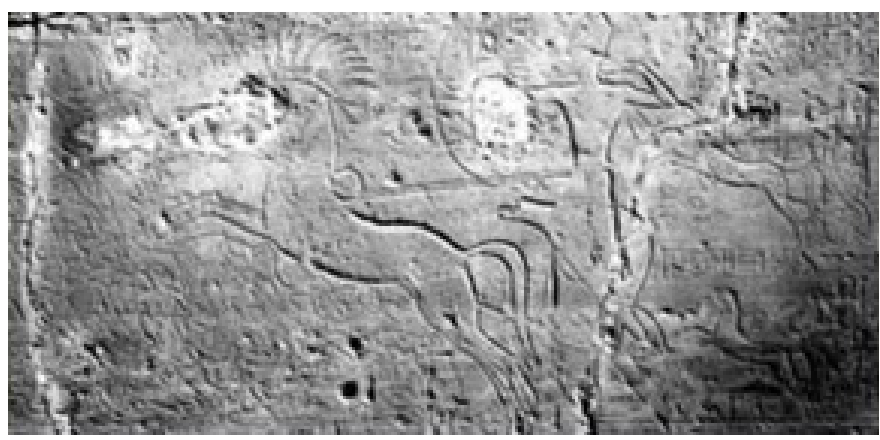

b

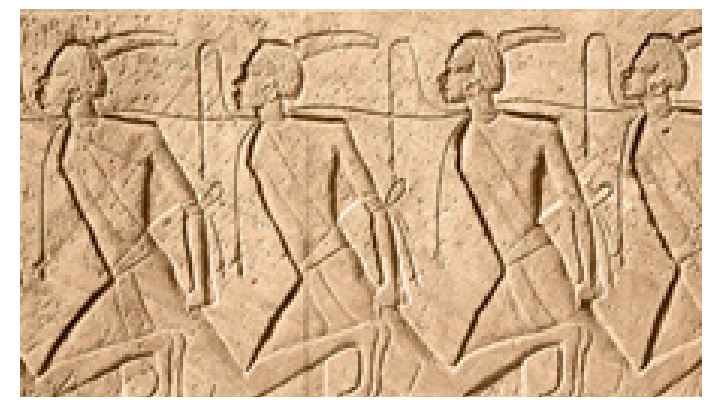

Fig. 4. Nubia in Ramses's Temples: (a) Ramses II strikes a Nubian chief (Beit el-Wali), (b) Nubians providing tribute to Ramses II, (c) Ramses II charging Nubians (Abu Simbel), (d) Nubian prisoners on the base of a seat to the left side of the entrance

ideal formula of stability. This symbol was so meaningful to ancient Egyptian that it had its own festival in the first day of shemu. ${ }^{52}$

The Osiride pillars, as those in this temple, were always engaged to other pillars, and not merged to them, where the original pillar was considered the backbone of the god. The Mummy-form Gestures of Osiris with the arms folded across the chest have also a meaning of themselves. The Pharaoh, who depicts himself in this form, merges himself with the everlasting god of the underworld and thereby indicates an everlasting nature of himself. It was usual that died queens and kings were mummified in this posture, but when Ramses II, had himself depicted in this form, while he is still alive, it means that he was claiming to be divine while still alive. ${ }^{53}$ The djed was considered necessary to aid in the transformation of human flesh (the Pharaoh) into the spiritual form (Osiris). ${ }^{54}$

Osiride pillars were unusual in cult temples; they were a symbol of anti-change and eternal life. Unlike this, renowned ancient Egyptian capitals of closed and open Papyrus or Lotus flowers, which were the typical capitals in cult temple, were distributed in a certain way to symbolize the seasonal changes over the year. ${ }^{55}$

Another common symbolic image that appears frequently in this temple was the image of the Pharaoh smiting the enemies with a mace. This was symbolic of the Pharaoh's role of protecting his kingdom from chaos that many pharaohs were so portrayed, despite they never went to a battle. ${ }^{56}$ Curiously, some later works by Nubian kings had the same gesture. One of these is on the pylon of the Lion Temple at Naga. ${ }^{57}$

Sizes also had important symbolic significance in

52 MCDEVITT, http://www.egyptianmyths.net/djed.htm

53 GADALLA 2000, 39

${ }^{54}$ BARD 1999, 392

55 GADALLA 2000, 39

56 STROUHAL 1992, 9

57 LARSON 2006, 8
Ancient Egypt. The stratified sizes of god and human, parent and child or husband and wife are usually symbolic of relative status and power within Egyptian compositions. This is particularly clear in scenes that show the Pharaoh at a much larger scale than his enemies. In a similar manner, even fully adult children are frequently depicted standing beside their parents as tiny figures, even though their figures, hair and clothing leave no doubt as to their actual maturity. Relative sizing, hence, can tell how a pharaoh viewed his own status in relationship to gods, or how he viewed the status of women. ${ }^{58}$ It is therefore notable that Ramses depicts himself all over this temple, and all his temples, in equal size as that of the deities.

\section{3-2- Heidegger's fore-structures,}

In the following, the temple's anticipatory forestructures are explored in a trial to shed the light on its "historicality".

\subsubsection{The fore-sight (the point of view):}

The fore-sight, or, from which point of view Ramses wanted this temple to be seen, is the most crucial matter to understand this temple. It is important here to keep in mind that this temple was one of six rock-cut temples (in addition to two other freestanding temples) erected in Nubia by Ramses II. By the time of Ramses II, Nubia had been a colony for two hundred years, but its conquest was recalled in most of these temples (Fig. 4), ${ }^{59}$ with multiple scenes of Nubian prisoners and causalities.

Notable here that in the Ramesseum, which was Ramses II's house of millions of years, where his memory was to be kept alive after his death and where he was supposed to record his grandest works. ${ }^{60}$ Scenes of a campaign in Nubia

\footnotetext{
58 WILKINSON10-11,1992

59 ROSELLINI, 1843.

60 LECUYOT 2007 http://web.archive.org/web/20070606144645/http:// www.archeo.ens.fr/8546-5Gren/clrweb/7dguylecuyot/GLRamesseumWeb.
} 
or Nubian prisoners are completely missing. ${ }^{61}$ Neither there is any such records among the so many records that Ramses made on the walls of Luxor and Karnak temples.

To explain this, one needs to be aware of some aspects of ancient Egyptian history and traditions. The houses of millions of years on west bank of the Nile at Thebes, like the Ramesseum, were considered as part of the domain of Amun and were, hence, connected administratively to the temple of Karnak, which ran the economic foundations that sustained the cults. However, Seti I (Ramses's father) built his house of millions of years at Abydos, where he linked his royal cult to Osiris, who was seen as a deceased king of Egypt. Thus, Seti's temple was dedicated, somehow, to the institution of kingship as embodied in Osiris. ${ }^{62}$

In Nubia, the centers of the Egyptian occupation were the Egyptian cult temples; the administration of production and distribution was carried out in these temples, as economic and administrative centers. ${ }^{63}$ They were preliminary dedicated to the state-cults of Ra-Harakhti, Amun-Ra and Ptah, as well as some cults associated with dead Pharaohs, such as the cult of Sesostris III, established by Tuthmoses III. ${ }^{64}$

According to this tradition, it was normal that Ramses wanted to establish a similar center in Nubia that bears his name. To do so, he needed a cult to establish this center around it. However, instead of linking it to one of Egypt's principal gods, as his father did in Abydos, or to a dead Pharaoh, as Tuthmosis III did, it is obvious that he decided to dedicate it to himself, and made the Temple of Abu Simbel as the center, or the Karnak, of this domain. L. Török writes about this that "The cult of the Pharaoh reached its pinnacle under Ramses II' reign, who gave himself, while he was still alive,

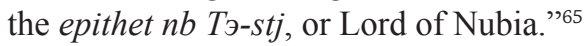

The other temples that were built by Ramses II in Nubia were, hence, probably all adherents to this center, as were the houses of millions of years adherent to the domain of Amun. This means that these temples were not there for religious reasons, where little actual priestly activity would seem available in such remote area ${ }^{66}$ but rather for economic and political reasons, where the cult was an ideological tool for political control. Establishing this cult in Nubia, on the western side of the Nile, the domain of the cult of Ramses was away, and independent, from the two domains of Amun: the one at Karnak in Thebes and the other at Gebel Barka in Nubia (as explained in 3.2.2.1-I), as well as from all the other domains on the eastern valley.

It is no wonder, then, that the Nubian people were the people addressed by this cult and this domain. Notable here is, also, that after the great earthquake that damaged the temple html

61 The scenes in the Ramesseum are: on the right wing of the pylon are inscriptions of the 118 cities that Ramses II conquered with scenes of Hittite prisoners. On the left wing, there are scenes of Kadesh battle and a siege of a Syrian city. On the front wall of the court, the scenes are again from the battle of Kadesh. On the sides of the entrance wall are scenes for siege of Dapur and Tunip (Syrian cities). On the outer wall of the vestibule is a scene depicting Ramses crowned by Sekhmet, Amun-Re and Khonsu. The scenes inside the sanctuary are for the barque's procession, the celebration of the Feast of the Valley and litanies to Ra-Harakhti and Ptah.

62 MORENZ 1992, 145

63 TÖRÖK 1997, 96-97

64 KAMIL 1993, 82

65 TÖRÖK 1997, 96-97

66 BADAWY 1968, 294 of Abu Simbel, the Egyptian viceroy of Kush-- Paser, was replaced by a Kushite viceroy--Setau, who supervised the maintenance work in Abu Simbel and the construction of the other temples afterwards. ${ }^{67}$

The adjacent temple of Nefertari provides a further proof in this regard. In Ancient Egyptian art, queens were generally represented as being smaller than pharaohs. However, in the façade of Nefertari's temple, Ramses ordered the statues of Nefertari to be of the same size as those of his own. She also appears in the same size as all the other deities in the wall reliefs inside the temple. It was not only unusual, but almost unprecedented for an Egyptian Pharaoh to honour his wife in this way. When a queen in Egypt was portrayed with the same size as her male consort, and even with the same size as the deities, this means that she rose to a status equal to the gods/pharaohs, becoming co-rulers, or at least as important in religious affairs. This appeared exclusively in the cases of: Nefertiti, Hatshepsut, and Nefertari. ${ }^{68}$

Ramses was the Pharaoh most interested in erasing the Amarna Period from history. In doing so, he certainly did not follow the tradition of Akhenaton, but rather the tradition of "God's Wives" of Nubian Queens. It was believed that they were literally married to Amun at the Karnak of Kush (Gebel Barkal) and thus held the rank of high priestesses as well as "goddesses" and were depicted in equal sizes to kings and gods. ${ }^{69}$ The fact that this temple was attend to Nubian people is further supported by an inscription over the entrance of this temple that reads "... for the chief queen Nefertari, beloved of $\mathrm{Mu}$, in Nubia, forever and ever, Nefertari for whose sake the very sun does shine."

\subsubsection{The fore-having (historical background):}

Knowing the foresight of the temple it is now easier to realize, which for-having is related to it, which will also point out the source of inspiration to its unique structure. Two major elements were found of relevance: symbols of the Nubian culture prior to this era; and the other temples that Ramses built in this region before, or simultaneously with this temple.

\subsubsection{Symbols of Nubian culture}

Prior to the Egyptian domination over Nubia, Nubian religion had its own deities with some prominent symbols that were of special religious value, namely Gebel Barkal and Deffufas.

\section{Gebel Barkal (Barkal Mountain)}

Gebel Barkal is a small mountain on the east bank of the Nile River that was the most significant landmark for the traders in Nubia. In Nubian belief, inselbergs in general were sacred to Amun, who "dwells" inside them. However, Gebel Barkal had a supreme theological importance as the abode of Amun, where all gods were born and the creation of the world took place. A great temple was built there to Amun by Tuthmoses III and was later expanded by Ramses II. ${ }^{70}$ Next to the Temple of Amun is the Temple of Mut -- the Egyptian Sky goddess and bride of Amun, which is a rock cut temple built

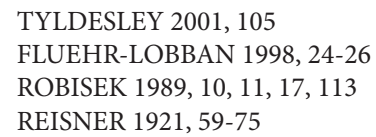



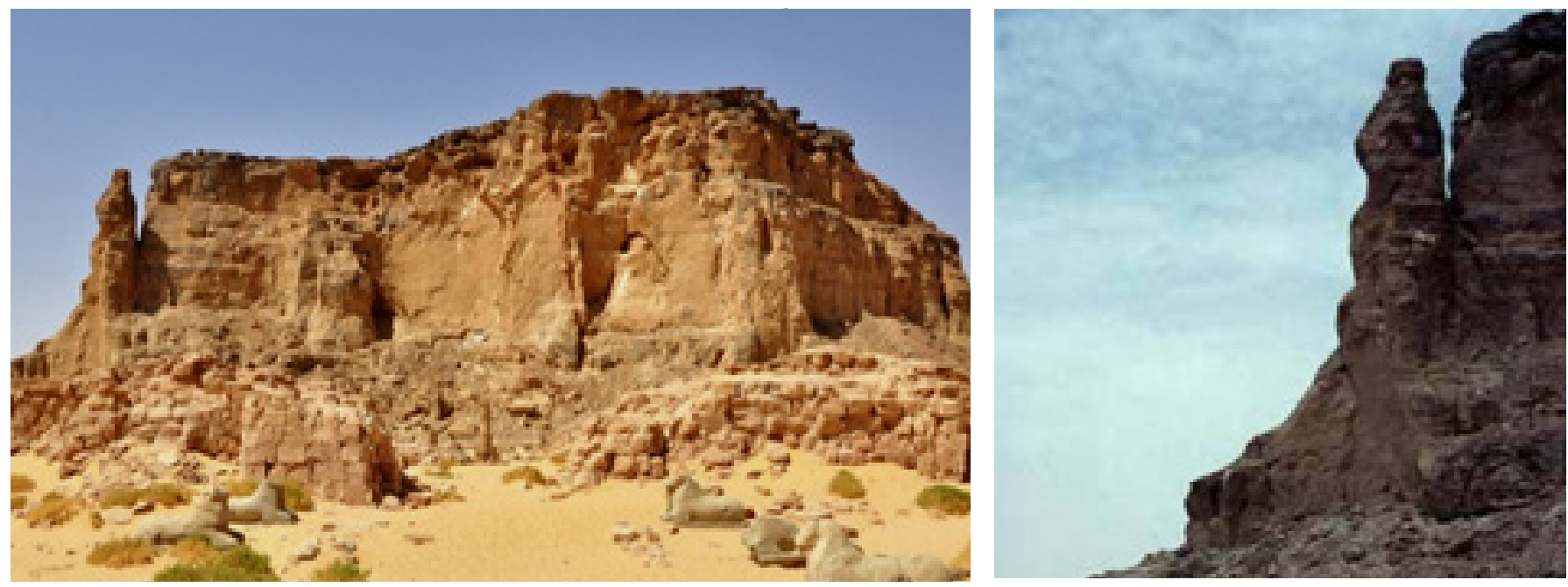

Fig. 5. Gebel Barkal: (left) the pinnacle to the left and the evenly spaced projections and (right) the pinnacle as it appears from the north-east, showing strong resemblance with the Egyptian White Crown

to the order of Taharqa. ${ }^{71}$

The most curious feature of Barkal Mountain is a pinnacle that projects from its southern corner (Fig. 5). For approximately two thirds of its height, it joins the cliff behind, higher up it stands free. To anyone familiar with ancient Egyptian art, the feeling that it is an Egyptian royal statue, with the unmistakable profile of the White Crown of Upper Egypt, is irrepressible. ${ }^{72}$ Waddington and Hanbury were the first people to write about this resemblance in $1820 .^{73}$ In 1897, E.A. Wallis Budge wrote: "it has all the appearance of a colossal statue. The Arabs declare that it is a statue of one of the kings, who reigned in the Time of Ignorance (i.e. before Islam)." 74

In 1939, the issue was raised in earnest by Major G. W. Titherington, then, the District Commissioner for Merowe, who pointed out that the pinnacle was only the most prominent of four large, equally sized, evenly spaced projections on the face of the cliff behind the temples. He then proposed that perhaps there had been not one but four huge statues there, just as at Abu Simbel. "The two middle forms are hardly more than scars left by ancient collapses of projecting rocks, while the far right one, destroyed in its upper half, seems at close range almost to suggest a pair of enormous legs emerging from a kilt." In his annual report for 1939, Anthony J. Arkell, the Sudan's Commissioner for Archaeology, referred to these theory. ${ }^{75}$

In 1941, G.H. Barter and J.W. Kenrick, visited Barkal Mountain to observe this wonder for themselves. Scanning the battered rock with binoculars, they found traces of an inscription with the unmistakable pair of cartouches just beneath the peak of the pinnacle. Arkell, duplicating the observation of Barter and Kenrick, found within the cartouches traces of hieroglyphs suggesting the name of Taharqa; it became obvious then that ancient man had indeed worked this stone in a place that seemed utterly inaccessible. ${ }^{76}$

\footnotetext{
${ }_{71}$ A pharaoh of the Ancient Egyptian 25th dynasty and king of the Kingdom of Kush

72 KENDALL 2004, 1-45

73 WADDINGTON/HANBURY 1822, 125

74 BUDGE 1897, 148

75 ARKELL 1961, 7-8

76 KENDALL 2004, 1-45
}

In 1957, the statue theory was given new impetus by H. N. Chittick, then, an inspector for the Sudan Antiquities Service. Like Arkell, he came away convinced that the four projections were indeed the remnants of huge statues. He also found remains of the sole surviving Bes colossus, which is one of eight colossi that used to support the hall's roof in the Temple of Mut, bringing in another evidence of the resemblance between this temple and Abu Simbel. ${ }^{77}$

Whatever the case may be, Taharqa's monument on its summit of Gebel Barkal was doubtless an attempt to merge himself forever with his divine father, who is "dwelling" within the mountain. ${ }^{78}$

\section{The Deffufas of Kerma}

Deffufas (Fig. 6) are unique mud-brick structures in Nubian Architecture, unparalleled elsewhere in the ancient world. Dating from 2500 BC, they likely served as the religious and political seat for the civilization of Kerma. ${ }^{79}$ Three known Deffufas were found: a Western Deffufa, an Eastern Deffufa, and a third little one that was recently discovered. The Eastern Deffufa is a few kilometres away from the river; the Western Deffufa is adjacent to it.

Although the religious nature of the Deffufas cannot be doubted, their precise function has not been determined. While some regard them as temples, others see them as administrative or defensive centers. ${ }^{80}$

Inside the two Deffufas were single columned halls, somehow similar to these in Egyptian rock-cut temples. Evidence of a limestone altar was found in the Eastern Deffufa. ${ }^{81}$ Areas of the exterior walls of the building were inlaid in stone and the floors were fancifully dressed with stone. $^{82}$

The Lower/Western Deffufa was the first that claimed Reisner's attention. ${ }^{83}$ As originally constructed, it probably stood to a height considerably greater than the still preserved 20 meter (the same height as Abu Simbel's colossi).

\footnotetext{
77 KENDALL 2004, 1-45

78 KENDALL 2004, 1-45

79 CLAMMER 2005, 159-160

80 CLAMMER 2005, 159-160

${ }_{81}$ GARLAKE 2002, 55

82 BIANCHI 2004, 78

83 BONNET 1992, 611-625
} 


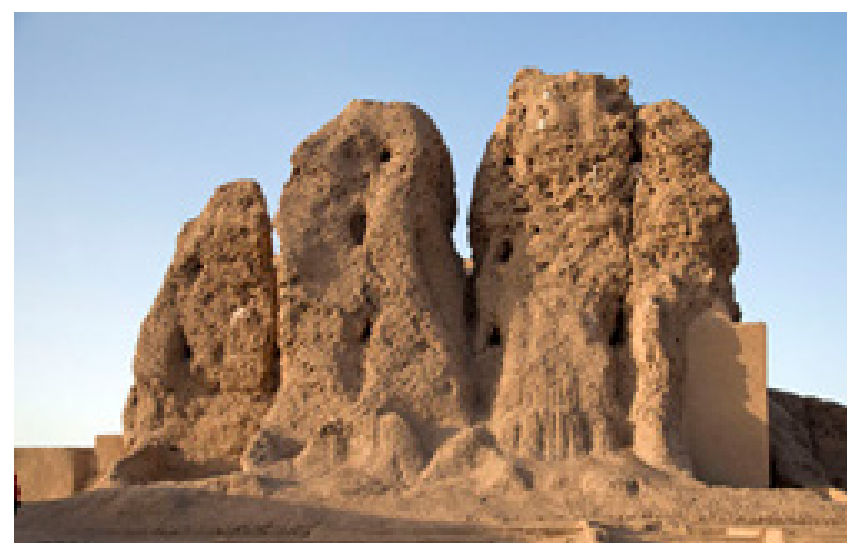

Fig. 6. The Deffufas of Kerma: (left) the Lower/Western Deffufa, and (right) the Upper/Eastern Deffufa

Reisner saw many links to ancient Egyptian works in this Deffufa. The character of the brickwork and the dimensions of the base in Egyptian cubits were indicative of Egyptian supervision. Sharing some aspects with the Middle Kingdom forts, he assumed that it was probably a fort that served to protect the river trade. ${ }^{84}$ He says: "The solid mass of brickwork, which towers above them, has customarily been regarded as some sort of defensive arrangement, and the complex as a whole has been called a fortified trading post." ${ }^{85}$ Yet the Deffufa seems to defend nothing but itself. Given this consideration, Säve-Söderbergh believes that the Deffufa might have been an enormous watchtower. ${ }^{86}$

However, the abundant refuse found within the western rooms furnishes more real clue as to the function of the Deffufa. Most conspicuous were fragments of 565 mud seal-impressions of Egyptian type affixed to pots, baskets, and wooden containers. There were also fragmentary remains of many objects of Egyptian manufacture, such as alabaster ointment jars, larger stone vessels, faience and pottery vessels, beads and stone crystals for making beads, and pieces of bronze. ${ }^{87}$ While the seal-impressions stand in a way for the administrative activities of the Egyptian occupation, the raw materials and the unfinished products stand for the manufacturing activities. Nevertheless, the main point stands out that the Deffufa was for the Egyptians a center of a considerable business in more or less valuable commodities, ${ }^{88}$ from which emanated that great Nile trade that Egypt was at such pains to protect, ${ }^{89}$ while for the Nubians, it was an important theological symbol as a manufactured replica of Gebel Barkal. ${ }^{90}$

\subsubsection{Temples of Ramses in Nubia:}

Despite of his several additions to the temples all over Egypt that includes 14 temples, curiously enough, all the temples that Ramses built from the ground up, except for the Ramesseum, were in Nubia, where he built six rock-cut and two freestanding temples. For Oakes, these temples were "part of a royal propaganda intended to intimidate the [local] population," ${ }^{91}$ despite were supervised by the Kushite viceroy

\footnotetext{
84 BONNET 1992, 611-625

85 REISNER 1923, 32; ARKELL, 1961, 68

86 SÄVE-SÖDERBERGH 1941, 115

87 REISNER, 1923, 32

88 REISNER, 1923, 32

89 REISNER, 1923, 24-25

90 SÄVE-SÖDERBERGH, 1941, 115-116

91 OAKES, 2003, 200
}

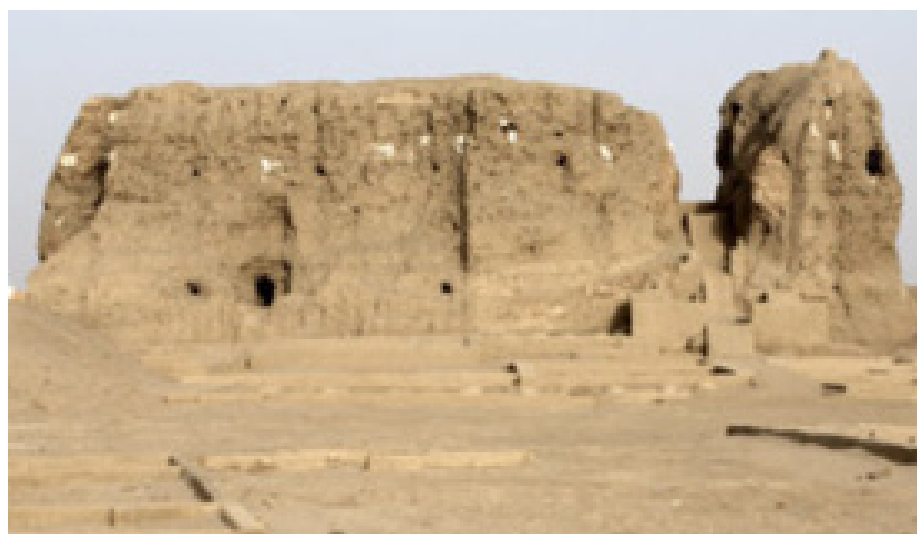

Setau, and prisoners from Libya (not Nubia) were employed in them. ${ }^{92}$ These temples (Fig. 7) include ${ }^{93}$ :

1- Temple of Beit el-Wali: is a rock-cut temple, which was dedicated to Amun-Ra, Ra-Harakhti, Khnum and Anuket. It was the first of Ramses II's temples in Nubia. The temple was originally fronted by a mud-brick pylon, ${ }^{94}$ and consisted of an entrance hall, a hypostyle hall and a sanctuary.

2- Temple of Gerf_Hussein: is a combination of rockcut and freestanding temple, dedicated to Ramses II, Ptah, and Ptah-Tatenen ${ }^{95}$. The basic plan is similar to that of Abu Simbel in a smaller scale, with the ceiling of the first hall supported by six Osirid pillars of Ramses II.

3-Temple of Wadi-Al-Sebua: is partially freestanding and partially rock-cut. It was the only one of this group of temples to be constructed on the east bank of the Nile and was dedicated to Ramses II, Amun-Ra and Ra-Harakhti. The temple had a mud-brick pylon with an approach lined with Ramses-headed-sphinxes. The court contained ten Osirid pillars of Ramses. At the rear of this courtyard, another mudbrick pylon once stood. ${ }^{96}$

4-Temple of Derr: is a rock-cut temple that consisted of two hypostyle halls, preceded by a (now lost) mud brick pylon, with engaged Osiride Pillars of Ramses II in the first one. The second hall gives way to the sanctuary, which contains four cult statues of Ramses II, Amun-Ra, Ra-Harakhti and Ptah, like those in Abu Simbel. ${ }^{97}$

5- Temple of Aksha: was dedicated to Ramses's royal statues: The Lord of Nubia. ${ }^{98}$ The remains of this temple are very fragmentary, containing five mud-brick chapels.

6- Temple of Amara West: of the sanctuary nothing remains but mounds of rubbish, except the lowest part of the walls, reposing upon a substructure of bricks burnt in the sun. The walls were probably built of alternate layers of stone and brick. ${ }^{99}$

Considering the architecture of these temples, some common features are easy to recognize: except for Wadi-

\footnotetext{
92 TÖRÖK, 2009, 189

93 WILKINSON, 2003.

94 ARNOLD / STRUDWICK, 2003, 29, 103

95 Ptah was a creator god in ancient Egypt and was merged with the Nubian creator god Tatenen as Ptah-Tatenen, which was worshiped in both Egypt and Nubia. GRIMAL, 1992, 260

96 BAINES/MÁLEK 1982, 180-183

97 TÖRÖK 1997, 337

98 ZIBELIUS-CHEN 1988, 273; TÖRÖK 2009, 96-97

99 BURCKHARDT 1819, 126-128
} 

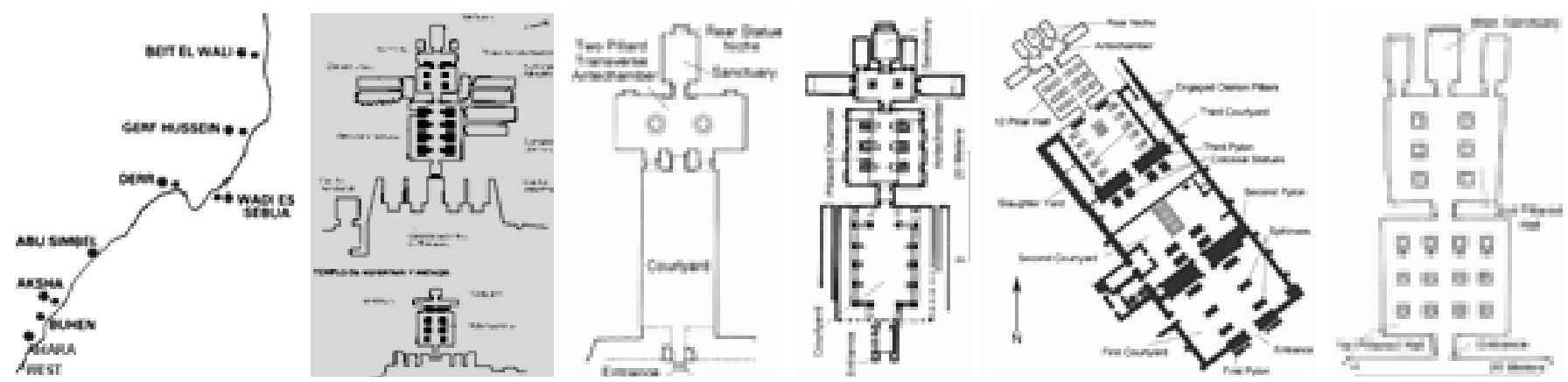

Fig. 7. Rock-cut temples of Ramses II in Nubia: (from left to right) Map of Ramses's Temples in Nubia - The two temples at Abu Simbel- Temple of Beit el-Wali - Temple of Gerf Hussein - Temple of Wadi-Al-Sebua- Temple of Derr (developed after WILKINSON 2000)

Al-Sebua, they lay on the western side of the Nile (the one temple on the eastern side might have been meant emphasize the non-funerary nature of the whole collection); Ramses's "invention" 100 of rock-cut temples ${ }^{101}$ was the dominant style in these temples, with free-standing parts, where, unusually, mud-brick is widely used; except for Beit el-Wali, they were dedicated to Ramses himself with, or without, other deities; they all contain colossal statues for the -still alive- defied Ramses; and finally they had similar plans like that of Abu Simbel, but in smaller scale. This means that these temples were, in a way or another, built to be a unified collection with common feature and unique style of their own that brings them together and distinguishes them from other temples.

\subsubsection{The fore-conception: the pre-knowledge:}

The idea of the defied Pharaoh and the symbolic expressions related to it are the most important foreconcept to be understood in order to "interpret" this temple. In ancient Egypt, the Pharaoh was an intermediary between humankind and the divine. It was believed that, upon his death, the Pharaoh becomes fully divine and assimilated with Osiris and $\mathrm{Ra} .{ }^{102}$ Cults associated with the living pharaoh were very limited, and were linked to very few Pharaoh with specific political and religious circumstances. One important tool of this Royal Cult was sculpture, which was considered as a divine work. The ancient Egyptian word for sculptor literally means he who keeps alive. Thus, sculpture was seen as a tool that helps the king achieve immortality, and sculptured figures were seen as a more elaborate way of embalming, by which the Pharaoh stays alive after his death. ${ }^{103}$

In the $30^{\text {th }}$ year of his reign, Ramses, among very few Pharaohs, celebrated his Sed festival, during which he was ritually transformed into a god. However, the construction of the temples, where he was clearly depicted as a living full god, was already ordered 20 years earlier. The following are some observations that give proof to this fact (Fig. 8). ${ }^{104}$

1. He put himself in one unity with the ancient Egyptian deities-trinity, where he sits with them on the same bench and with the same size in the sanctuaries of Abu Simbel and Derr.

\footnotetext{
100 Although the Temple of Queen Hatshepsut (18th Dynasty-1480 B.C) was the first rock-cut temple in Egypt, but it was rather shallow work and did not cut very deep in the mountain. The first work that went really deep into the mountain was that of Seti I, which Ramses himself, as a coregent with his father, had supervised most of its construction process until after his father's death

101 KAMIL 1993, 124

102 WILKINSON 2003, 60-63

103 THE ARTCHIVE http://www.artchive.com/artchive/E/egyptian.html

104 KITCHEN 1982
}

2. In the first side room of Abu Simbel, Ramses is depicted making offers for Amun, Mut and "himself" sitting between them. The defied Ramses in this scene, and several similar scenes, has the formal spade-like beard, which means that he is still alive (a dead Pharaoh should not have such formal beard). ${ }^{105}$

3. A figure of Ramses as falcon-headed in one of the side chambers at Abu Simbel

4. The temple of Aksha, which is dedicated to Ramses's royal statue User Ma'at Ra the Lord of Nubia alone, in addition to several other temples dedicated to him with other deities.

5. A plaque of Ramses's Vizier in the State Museum of Egyptian Art, Munich, on which he calls Ramses, "the supreme god" or "the lord of heaven."

6. Several scripts on the walls of the temple of Seti I that came in the form of "letters" from Ramses's father, his Vizier, and different deities, in which Ramses was addressed as "the supreme deity" and the "lord of deities."106

7. Remains of several colossal statues for him in his capital Br-Ramses, with different names like "the evident between Gods," "the beloved by Atum,"...etc, which were worshiped during Ramses's life in what S. Hassan describes as "Ramses's cult of colossal statues."107

8. At this time, the rule was that the sons and

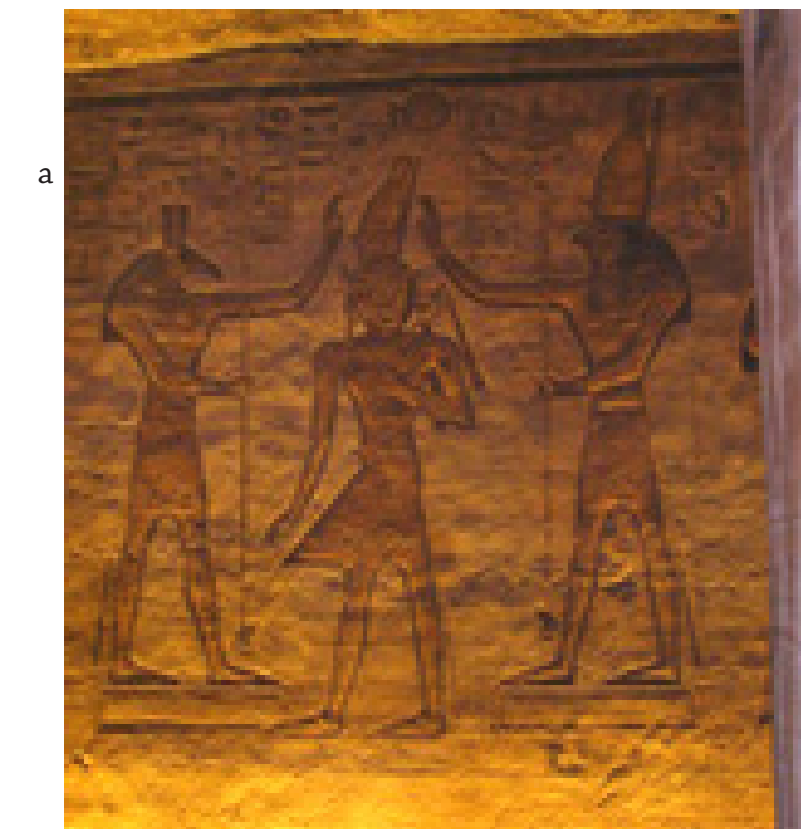
05 HASSAN 1956, 477
106 HASSAN 1956, 468
107 HASSAN 1956, 512 

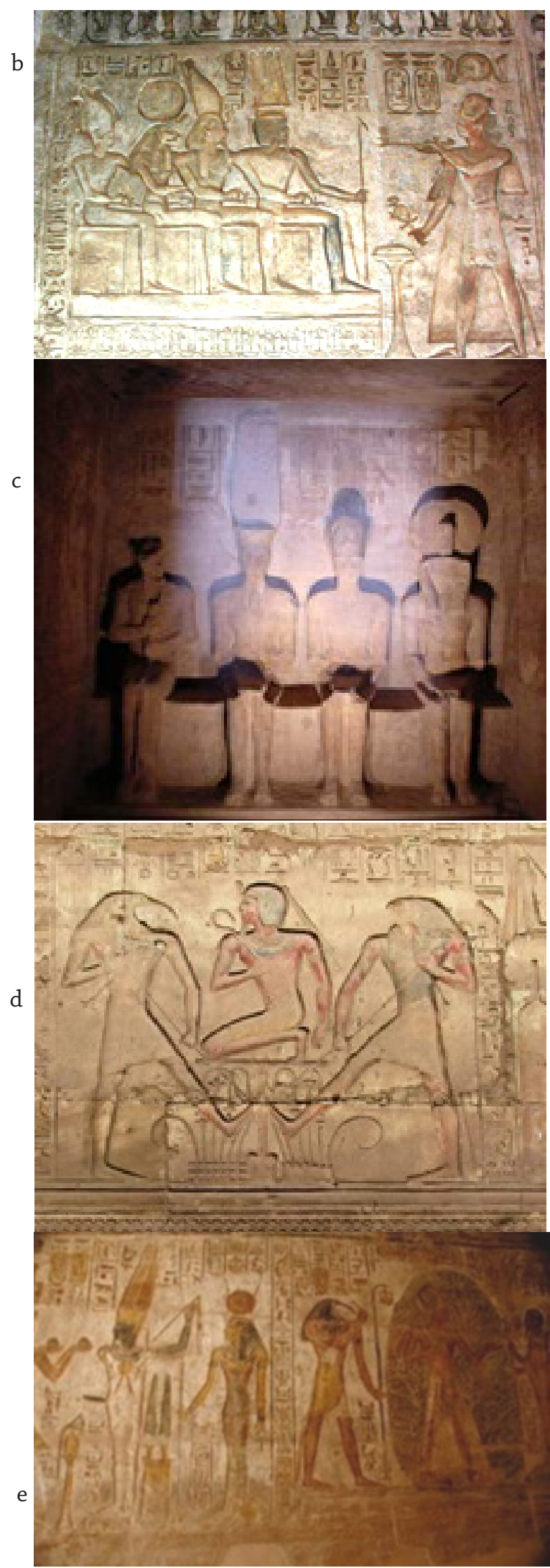

Fig. 8. Ramses and the deities: (a) Set and Horus crowning Ramses, with a step made under their feet, so that the Pharaoh do not have to bow; (b) Ramses praying for himself among other deities, (c) Ramses sitting on the same bench with the three state deities in the sanctuary of Abu Simbel; (d) Horus and Thoth wreathing the floral emblems of Upper and Lower Egypt under the Ramses's feet - (e) Re-Harakhti writing the name of Ramses on the leaves of the sacred persea tree, which refers to an everlasting life. In all cases, it is notable that Ramses was depicted in the same size as the deities. daughters of the Pharaoh appear in small, or even tiny, size beside his own figure, as Ramses himself did in this temple. Nevertheless, it is notable that there is no such figure for Ramses in his father's temple. In the figure of his coronation as a crown prince (before his coronation as a coregent), the then 13-years-old Ramses is depicted in equal size to his father and to the other three deities, who appear in the same figure watching the coronation. In a scene in the hypostyle hall in the Karnak temple, Ramses appears as a crown prince in the Valley Festival, where he takes the roles of both the Pharaoh and the High Priest in the barque of Ra, while his father (the actual king then) is in the entourage of the ship. ${ }^{108}$

\section{RESULTS AND DISCUSSION:}

From the analyses in the previous section, the overall quality of the Genius Loci of the temple could be summarized as supremacy and domination.

The design scheme of the temple is unparalleled in ancient Egyptian architecture. Its location (so is the location of the other Ramses's temples in Nubia) on the western side of the valley is also unusual and confusing. It has a setting that symbolizes the solid, hazardous, divine, and intimidating nature of the location, in a formal structure that conveys simplicity, high skills, memorable qualities, and rootedness. Special emphasizes was given in the decoration to the idea of Ramses as a full god, who is a fearful and invincible against his enemies, namely Nubians. The temple has a significant symbolic use of light that conveys both religious and political messages of permanence and dominating presence. Symbolic expression in the temple is generally connected to custodial ideas like keeping order, protection and guardian powers.

In ancient Egypt, temples were more complicated than any structure that we know now. The term "temple" was very misleading and covering a huge variety of different structures that evolved over such a large period. In the case of Egypt almost every structure other than tombs, is referred to as temple. ${ }^{109}$ They were "acting sometimes as fortresses, administrative centers and even concrete expression of propaganda or royal retreats."

With evidences that show that the, unusually multiple, side chambers were used for some non-ritual activities, it is very possible that the temple of Abu Simbel was one of these cases, where a god's mansion was built as much for administrative/political as for religious purposes. By joining the three state gods of the main three regions of Egypt on the same bench and with the same size, Ramses evidently declare himself the god of a fourth region -- Nubia, where he erected a group of temples, which were the only temples that he built from the ground up. These temples were designed as a unified collection: they had certain distinguishing architectural characteristics in common, were mostly dedicated to Ramses himself, and they were full of intimidating scenes for Nubian prisoners that were not seen in Ramses's other works.

Explaining this trend, Lindsay Jones wrote about "the communicative aspects of architecture," where he defines two types of communication to be conveyed through scared architecture: divinity, where sacred architecture

\footnotetext{
108 GHORBAL 1957, 39

109 DUNN 2011, http://www.touregypt.net/featurestories/temples.htm

110 DUNN 2011, http://www.touregypt.net/featurestories/temples.htm
} 
commemorates, houses, and/or represents a deity, and politics, where sacred architecture commemorates, legitimates, or challenges socioeconomic hierarchy and/or temporal authority. ${ }^{111}$

Applying this on ancient Egyptian architecture, the first to be noted is that significant changes in temples' architecture usually took place in accordance with remarkable political occasions, as was the case with the Temple of Hatshepsut. The notable shift in the design that appeared in Ramses's temples in Nubia, with tendency to create a new style, in which temples are merged within mountains, was certainly a sign of some political/religious change.

In Nubia, economic and administrative centers were preliminary adherent to the cult centers of the state gods, as well as the cults associated with the Pharaoh. Ramses, expectedly, wanted to establish such center that bears his name, to be his own economic and administrative center for the Nubian treasures. The, unusually huge, side chambers of Abu Simbel, were obviously where Nubian gold and different valuable goods were stored. However, instead of linking this cult to one of the principal gods, he linked it to himself. For the central temple of the cult - the temple of Abu Simbel, Ramses chose a mountainous spot, where he -according to the Nubian beliefs- can merge himself with his divine father "dwelling" in the mountain and produce his own "Karnak". All the temples that he built in this region were adherents to this cult, with their economic/administrative center in the temple of Abu Simbel. Linking this group of temples to Nubia is frankly proclaimed over the entrance of Nefertari's temple and on the statue of the Lord of Nubia in Aksha.

On another hand, at a time, where the limits of the civilization were defined by the limits of the cult and the borderlines of the country were put where different deities start to come into the view. It was normal that the Kushite belief in the primacy of their Karnak as granted by Amun of Gebel Barkal was a continuous source of discomfort for Egyptian pharaohs that sometimes developed into conflicts. ${ }^{112}$ Therefore, it was quite understood that Ramses wanted to defeats this cult forever by establishing another cult in the region, which can rival the values and symbols of the first cult, using the same conceptual tools and compositional vocabulary of the first cult. The rock-cut temples, reaching a climax at the Great temple of Abu Simbel were, therefore, designed to be linked with the major religious symbols of Nubian civilization; namely the Deffufas and Gebel Barkal, by formal, conceptual, religious, and political clues.

Being an inselberg, like Gebel Barkal, with (although man-made) cave-dwelling for the god, Amun was seen to be present inside the mountain at Abu Simbel, as he was in Gebel Barkal. ${ }^{113}$ Ramses then used all possible ways of "propaganda" to equate himself with Amun or maybe even rival him. On another hand, the relationship between the pinnacle(s) of Gebel Barkal and Ramses's temple at Abu Simbel, whether it is natural or man-made structure, is unmistakable. If it is a natural one, then Ramses had certainly tried to rival it by the four colossi; and if man-made colossi were once made there, then it is unquestionable that it was a failing attempt to rival

\footnotetext{
111 JONES 2000, 11-22

112 KENDALL, 2004, 1-45

113 KENDALL, 1997, 169
}

Ramses's Abu Simbel.

Ramses's desire of religious supremacy appeared since the very first year of his reign, when he appointed a new priest for the Karnak from the priests of Middle Egypt and not the priests of Thebes as usual. ${ }^{114}$ In the same sequence, historians had also mentioned that Ramses ordered the construction of multiple edifices or towers from sun-dried-brick, but none of them had survived. The actual function of these towers is dilemmatic, some say that their purpose was that Ramses wanted to "touch the sky"; others suggest that they were meant as watchtowers. ${ }^{115}$ Ramses's Palace in Br-Ramses was said to have been in itself one of the highest structures of sun-driedbrick that it was called $b r$ 'oo, or the "lofty house."116 This leads directly to the very high, mud-brick Deffufas, which had been also seen as possible watch towers as well as religious symbols.

Deffufas, despite were originally Egyptian work, were seen by the Nubians as "a representation in brick for Gebel Barkal,"117 or "an artificial sacred mountain."118 They were seemingly a previous, successful, Egyptian trial in the same direction of replication Gebel Barkal. The frequent, atypical use of mud-brick in the pylons of Ramses's temples in Nubia raises a question mark about the motives behind this structural shift, which might be answered by taking the mud-brick Deffufas into consideration.

So, the cult of Ramses with its center at Abu Simbel, and its adherent rock-cut temples with mud-brick pylons, was seemingly meant as a competitor for the cult of Amun of Gebel Barkal and its Deffufas not only in terms of hugeness, but also rather in terms of phenomenality, miraculous structure, and inimitable presence.

\section{CONCLUSION}

The conclusion of this study comes in two folds: on one hand, it had been shown that the temple of Ramses at Abu Simbel was not just another God's Mansion, but also rather a unique structure on all levels. With the creation of new cult dedicated to himself, away from the domain of Amun, where Abu Simbel was the center of the cult and the other temples that he built in Nubia adherent to it, Ramses took the final decisive step towards equating the living Pharaoh with gods. The Temple of Abu Simbel and its "domain" on the western side of the Nile within the Nubian territory, actualized his claim as a supreme god and "Lord" of the flourishing region of Nubia, the gold and copper of which were of great importance to Egypt.

Several evidences had been driven to prove that, by joining the three state gods on the same bench and with the same size, Ramses declared himself the god of the fourth region of Egypt--Nubia, with the center of his cult at the temple of Abu Simbel. The significance Genius Loci, the phenomenal presence, and the rootedness of the uniquely designed temple within the solid mountain were all strong references to an eternal presence of Ramses in the region.

More than being a House of the God, the temple of Abu Simbel was a statement to the Nubians of the lordship
114 HASSAN, 1956, 457
115 HASSAN, 1956, 462
116 GHORBAL, 1957, 23
117 KENDALL, 1997, 324
118 WILLIAMS, 2006, 150-157 
of the Ramses over Nubia, employing different means of architectural expression to convey two specific messages. The first one, it is that Ramses puts himself in an equal status to that of the principle deities while the second one it is a threatening message to the Nubians, who would become "enemies". With a style that was more associated with the symbols of Nubians culture than it was with the ancient Egyptians, and with its higher metaphorical effect and stronger presence as a landmark, the temple was a strong subjugator, not for the Egyptian Karnak, but rather for the Nubian Krank of Gebel Barkal and its copies in the Deffufas and their cults. Seemingly, the temple had also served for similar functions like that of the Deffufa, which was a center of considerable business in more or less valuable commodities and was thought to have been also used as watchtower.

For contemporary architects, the interpretation of the temple, as introduced in this study, provides a very wealthy example of how a building can have a Genius Loci and how a place can be meaningful.

On the other hand, in terms of methodological attainment, it had been attested that hermeneutic analysis is a useful tool that has the ability to discover new dimensions about historical architecture and archaeological sites. Especially where the relationship between the parts and the whole and then between the whole and a bigger whole had been employed to arrive at a more detailed identification of the temple and decode its discourse. Reaching this conclusion, the present paper opens the door for situating the hermeneutic approach, which had been disregarded for a long time, within the research tradition of historical architecture and archaeology.

\section{REFERENCES:}

\section{ARKELL 1961}

Arkell, A. History of the Sudan: from the earliest times to 1821 (London: Athlone Press)

ARNOLD/STRUDWICK, 2003

Arnold, D./Strudwick, N., The Encyclopedia of Ancient Egyptian Architecture (London: I.B. Tauris Publishers).

ARTIBISE 2010

Artibise, Y., What is Genius Loci. Urbanism (http:// yuriartibise.com/what-is-genius-loci/)

ASSMANN 2008

Assmann, J., Of God and Gods (Wisconsin: University of Wisconsin Press).

BARD 1999

Bard, K. A., Encyclopedia of the Archaeology of Ancient Egypt (London: Routledge).

BADAWY 1968

Badawy, A., A History of Egyptian Architecture: The Empire (the New Kingdom) From the Eighteenth Dynasty to the End of the Twentieth Dynasty 1580-1085 B.C. (California: University of California Press).

BAINES 1982

Baines, J. and J. Málek. Atlas of Ancient Egypt (New York: Facts on File Publications).

BIANCHI 2004

Bianchi, R. S. Daily Life of the Nubians (Calfornia: Greenwood Publishing Group).

BONNET 1992

Bonnet, C., Excavations at the Nubian royal town of Kerma: 1975-91, Antiquity 66(252), 611-625

BUDGE 1897
Budge, E.A., The Nile: Notes for Travellers in Egypt (London: Luzac and Co.)

BUDGE 1959

Budge, W., The Egyptian Religion (New York: University Books).

BURCKHARDT 1819

Burckhardt, J. L., Travels in Nubia (London: John Murray).

CLAMMER 2005

Clammer, P., Sudan: Bradt Travel Guides (California: Globe Pequot Press).

EL-BIZRI 2011

El-Bizri, N., Being at Home Among Things: Heidegger's Reflections on Dwelling, Environment, Space, Place 3, 47-71.

FAULKNER 1994

Faulkner, R. and O. Goelet. The Egyptian Book of the Dead: The Book of Going Forth by Day (San Francisco: Chronicle Books).

FLUEHR-LOBBAN 1998

Fluehr-Lobban, C., Nubian Queens in the Nile Valley and AfroAsiatic Cultural History (Boston: Museum of Fine Arts).

FORMAN/QUIRKE 1996

Forman, W./Quirke, S., Hieroglyphs and the Afterlife in Ancient Egypt (Norman: University of Oklahoma Press).

GADALLA 2000

Gadalla, M. Egyptian Harmony: The Visual Music (North Carolina: Tehuti Research Foundation).

GARLAKE 2002

Garlake, P. S. Early art and architecture of Africa (Oxford: Oxford University Press).

GHORBAL 1957

Ghorbal, Sh. Egypt throughout Ages (Cairo: Ministry of Media) (in Arabic)

GRIMAL 1992

Grimal, N. A History of Ancient Egypt (Oxford: Blackwell Books).

GRONDIN 1994

Grondin, J. Introduction to Philosophical Hermeneutics (New Haven: Yale University Press).

HARRIES 1997

Harries, K. The Ethical Function of Architecture (Cambridge, MA: The MIT Press).

HASSAN 1956

Hassan, S. Encyclopedia of Ancient Egypt (Cairo: Cairo University Press) (in Arabic).

HEIDEGGER 1971

Heidegger, M., The Thing. In: Hofstadter, A. (ed.), Poetry, Language, Thought (New York: Harper and Row), 172-174.

HEIDEGGER 1993

Heidegger, M., Building Dwelling Thinking. In: Krell, D.F., (ed.) Basic writings (New York: Harper Collins Publishers), 347-63.

HEIDEGGER 1993: 143-212

Heidegger, M., The Origin of the Work of Art. In: Krell, D.F., (ed.) Basic writings (New York: Harper Collins Publishers), 143-212.

IRBY/MANGLES 1823

Irby, Ch./Mangles, J., Travels in Egypt and Nubia, Syria and the Holy Land during the Years 1817-1818 (London: T. White).

JIVE ' N 2003

Jive'N, G./Larkham, P.J., Sense of Place, Authenticity and Character: A Commentary, Journal of Urban Design 8 (1), 67-81.

JONES 2000

Jones, L., Hermeneutics of Sacred Architecture (Cambridge: Harvard University Press) 
KAMIL 1993

Kamil, J., Aswan and Abu Simbel: History and Guide (Cairo: The American University in Cairo Press).

KENDALL 1997

Kendall, T., Kerma and the Kingdom of Kush 2500-1500B.C.; the Archaeological Discovery of an Ancient Nubian Empire (Washington: University of Washington Press).

KENDALL 2004

Kendall, T., The Monument of Taharqa on Gebel Barkal. In: Wenig, S. (ed.), Neueste Feldforschungen im Sudan und in Eritrea: Akten des Symposiums vom 13. bis 14. Oktober 1999 in Berlin [Meroitica 21] (Berlin: Harrasowitz), 1-45.

KITCHEN 1982

Kitchen, K., Pharaoh triumphant: The Life and Times of Ramses II, King of Egypt (London: Aris \& Phillips).

LARSON 2006

Larson, J. A., Lost Nubia: A Centennial exhibit Photography from 1905-1907 Egyptian Expedition of the University of Chicago (Chicago: University of Chicago).

LECUYOT 2007

Lecuyot, G., The Ramesseum (Egypt): Recent Archaeological Research. Paris: Archéologies d'Orient et d'Occident, (http://web.archive.org/web/20070606144645/http:// www.archeo.ens.fr/8546-5Gren/clrweb/7dguylecuyot/ GLRamesseumWeb.html)

MORENZ 1992

Morenz, S., Egyptian Religion, Keep A. E (tr.) (Ithaca, NY: Cornell University Press).

MURRAY 1920

Murray, M.A., Ancient Egyptian Legends (London: John Murray).

NORBERG-SCHULZ 1980

Norberg-Schulz, C., Genius Loci, towards a phenomenology of architecture (New York: Rizzoli).

OAKES 2003

Oakes, L. Pyramids, Temples and Tombs of Ancient Egypt: An Illustrated Atlas of the Land of the Pharaohs (London: Hermes House: Anness Publishing).

PARKER 1950

Parker, R., The Calendars of Ancient Egypt, Studies in Ancient Oriental Civilization (Chicago: University of Chicago Press).

REDFORD. 2002

Redford, D.B., The Ancient Gods Speak: A Guide to Egyptian Religion (Oxford: Oxford University Press).

REISNER 1923

Reisner, G.A., Excavations at Kerma, Parts 1-3. Harvard African Studies, Vol. 5 (Cambridge: Harvard University Press).

ROBISEK 1989

Robisek, C., Das Bildprogramm des Mut-Tempels am Gebel Barkal. Beiträge zur Ägyptologie (Wien: Rundle-Clark).

ROSELLINI 1843

Rosellini, I,. Monumenti dell' Egitto e della Nubia (Pisa: Presso N. Capurro).

SÄVE-SÖDERBERGH 1941

Säve-Söderbergh, T., Ägypten und Nubien: Ein Beitrag zur Geschichte altägyptischer Aussenpolitik (Lund: H. Ohlssons boktryck).

SHARR 2007

Sharr, A., Heidegger for Architects (New York: Routledge)

SOLLEH 2011

Solleh, K., The Damby Tradition of the Kone People of Sierra

STROUHAL 1992
Strouhal, E., Life of the Ancient Egyptians (Oklahoma: University of Oklahoma Press).

TÖRÖK 1997

Török, L., Der Nahe und Mittlere Osten (Leiden: Brill).

TÖRÖK 2009

Török, Between Two Worlds: The Frontier Region between Ancient Nubia and Egypt 3700 BC 500 AD (Leiden: Brill).

TYLDESLEY 2001

Tyldesley, J., Ramesses: Egypt's Greatest Pharaoh (London: Penguin Books).

WADDINGTON/HANBURY 1822

Waddington, G./Hanbury, D., Journal of a Visit to Some Parts of Ethiopia (London: John Murray).

WILSON/HUTCHINSON 1991

Wilson, H./Hutchinson, S., Triangulation of qualitative methods: Heideggerian hermeneutics and grounded theory, Qualitative Health Research 1, 263-276.

WEIGALL 1910

Weigall, A. A Guide to the Antiquities of Upper Egypt, from Abydos to the Sudan frontier (London: Methuen \& co., LTD.).

WILKINSON 1992

Wilkinson, R.H., Reading Egyptian Art: A Hieroglyphic Guide to Ancient Egyptian Painting and Sculpture (London: Thames \& Hudson).

WILKINSON 2000

Wilkinson, R.H., The Complete Temples of Ancient Egypt (London: Thames \& Hudson).

WILKINSON 2003

Wilkinson, R.H., Complete Gods and Goddesses of Ancient Egypt (London: Thames \& Hudson).

WILLIAMS 2006

Williams, B., The Cave Shrine and the Gebel. In Timelines, Studies in Honor of Manfred Bietak, Vol III, ed. E. Czerny et al (Leuven: Leuven university), 150-157.

ZIBELIUS-CHEN 1988

Zibelius-Chen, K., Die Agyptische Expansion Nach Nubien: Eine Darlegung Der Grundfaktoren (Wiesbaden: Dr Ludwig Reichert).

\section{Websites:}

Ancient-wisdom "Rock-cut Temples: Abu Simbel. Accessed at November 24 2014, http://www.ancientwisdom.co.uk/egyptabusimbel.htm

Dunn, J. Tour Egypt "Temples of Egypt, Accessed at November 24 2014, http://www.touregypt.net/ featurestories/temples.htm

McDevitt, A. Ancient Egypt: the Mythology "The Djed" Accessed at November 24 2014, http://www.touregypt.net/ featurestories/temples.htm; http://www.egyptianmyths. net/djed.htm

Planetware "Abu Simbel. Accessed at November 24 2014, http://www.planetware.com/nubia/abu-simbel-egyasw-abusim.htm

Saleh, A. Nubiat "Saving Abu Simbel (in Arabic) Accessed at November 24 2014, http://nubiat.blogspot. com/2013/09/blog-post 7981.html

The Artchive Egyptian art Accessed at November 24 2014, http://www.artchive.com/artchive/E/egyptian.html

Wells, M. Ancient Nubia, Egypt. “A Glimpse of Egypt's Ancient Nubia Accessed at November 24 2014, http://www. soulofamerica.com/ancient-nubia.phtml 